\title{
NEUTRON ACTIVATION AS A ROUTINE METHOD FOR THE DETERMINATION OF TRACE ELEMENTS IN WATER
}

\author{
K. H. LIESER, W. CALMANO, E. HEUSS, V. NEITZERT \\ Fachbereich Anorganische Chemie und Kernchemie, Technische Hochschule Darmstadt, \\ D-61 Darmstadt (FRG)
}

(Received November 15, 1976)

\begin{abstract}
By freeze-drying the following elements can be determined in natural water except sea water: $\mathrm{Au}, \mathrm{Ba}, \mathrm{Br}, \mathrm{Ca}, \mathrm{Ce}, \mathrm{Co}, \mathrm{Cr}, \mathrm{Eu}, \mathrm{Fe}, \mathrm{K}, \mathrm{La}, \mathrm{Mo}, \mathrm{Na}, \mathrm{Sb}, \mathrm{Sc}, \mathrm{Se}, \mathrm{U}, \mathrm{Zn}$. Some problems may arise with respect to $\mathrm{As}$ and $\mathrm{Hg}$. $\mathrm{Cu}, \mathrm{Cd}$ and $\mathrm{Ni}$ can only be determined if present in high concentrations. Separation by adsorption on charcoal in presence of complexing agents gives yields between 75 and $100 \%$ for the following elements in sea water: $\mathrm{Ag}, \mathrm{Au}, \mathrm{Cd}, \mathrm{Ce}$, $\mathrm{Co}, \mathrm{Cr}, \mathrm{Eu}, \mathrm{Fe}, \mathrm{Hg}, \mathrm{La}, \mathrm{Mo}, \mathrm{Sc}, \mathrm{Se}, \mathrm{U}, \mathrm{Zn}$ (As 67\%, Sb 56\%). Activation or use of labelled ions and study of exchange give information about mobility of trace elements in suspended matter.
\end{abstract}

\section{Introduction}

For routine analysis simple procedures and reproducible results are essential. The following points are important: (a) Non-destructive determination. (b) Determination of the greatest possible number of elements relevant for the environment (multielement analysis). The elements which can be determined by routine neutron activation analysis, the influence of imputities in the quartz ampoules, the interferences and the reproducibility of the results were studied in detail. The samples were irradiated in the research reactor FR2 in Karlsruhe at a flux of $9 \cdot 10^{13}$ $\mathrm{n} \cdot \mathrm{cm}^{-2} \cdot \mathrm{sec}^{-1}$ for $1-3$ days and measured after a decay time of 1 day or more. $\mathrm{Fe}$ was used as standard.

\section{Freeze-drying}

The following elements can be determined in natural water except sea water by freeze-drying without difficulties: $\mathrm{Au}, \mathrm{Ba}, \mathrm{Br}, \mathrm{Ca}, \mathrm{Ce}, \mathrm{Co}, \mathrm{Cr}, \mathrm{Eu}, \mathrm{Fe}, \mathrm{K}, \mathrm{La}, \mathrm{Mo}$, $\mathrm{Na}, \mathrm{Sb}, \mathrm{Sc}, \mathrm{Se}, \mathrm{U}, \mathrm{Zn}$. Problerns arise with respect to the determination of As and $\mathrm{Hg}$. $\mathrm{Cu}, \mathrm{Cd}$ and $\mathrm{Ni}$ can only be determined if present in relatively high concentrations. 
Table 1

Relative mean values and standard deviations obtained by freeze drying and application of the Fe-monostandard method

\begin{tabular}{l|c|c|c}
\hline Element & $\begin{array}{c}\text { Concentration, } \\
\text { ppb }\end{array}$ & $\begin{array}{c}\text { Relative mean value } \\
\text { and standard } \\
\text { deviation, all values } \\
\text { included }\end{array}$ & $\begin{array}{c}\text { Relative mean value } \\
\text { and standard deviation } \\
\text { calculated according } \\
\text { to NALIMOW }\end{array}$ \\
\hline $\mathrm{As}$ & 1 & $1.81 \pm 2.4$ & $0.65 \pm 0.34$ \\
$\mathrm{Au}$ & 0.01 & $0.36 \pm 0.20$ & $0.36 \pm 0.20$ \\
$\mathrm{Ba}$ & 100 & $0.67 \pm 0.037$ & $0.66 \pm 0.021$ \\
$\mathrm{Br}$ & 10 & $1.08 \pm 0.14$ & $1.08 \pm 0.14$ \\
$\mathrm{Ca}$ & $10^{5}$ & $1.04 \pm 0.17$ & $1.10 \pm 0.0$ \\
$\mathrm{Cd}$ & 1 & $4.11 \pm 3.12$ & $2.66 \pm 0.32$ \\
$\mathrm{Ce}$ & 0.1 & $1.84 \pm 0.91$ & $1.52 \pm 0.30$ \\
$\mathrm{Co}$ & 1 & $1.10 \pm 0.11$ & $1.10 \pm 0.11$ \\
$\mathrm{Cr}$ & 1 & $1.04 \pm 0.34$ & $0.99 \pm 0.30$ \\
$\mathrm{Cu}$ & 10 & $2.75 \pm 3.0$ & $2.75 \pm 3.0$ \\
$\mathrm{Eu}$ & 0.1 & $1.21 \pm 0.55$ & $0.89 \pm 0.13$ \\
$\mathrm{Fe}$ & 100 & $0.72 \pm 0.35$ & $0.72 \pm 0.35$ \\
$\mathrm{Hg}$ & 0.1 & $31.2 \pm 106$ & $1.63 \pm 0.77$ \\
$\mathrm{~K}$ & 1000 & $1.16 \pm 0.58$ & $0.89 \pm 0.24$ \\
$\mathrm{La}$ & 0.1 & $1.14 \pm 0.32$ & $1.14 \pm 0.32$ \\
$\mathrm{Mo}$ & 1 & $1.08 \pm 0.26$ & $1.25 \pm 0.0$ \\
$\mathrm{Na}$ & 5000 & $0.87 \pm 0.09$ & $0.86 \pm 0.08$ \\
$\mathrm{Sb}$ & 1 & $0.90 \pm 0.33$ & $1.01 \pm 0.12$ \\
$\mathrm{Sc}$ & 0.02 & $1.29 \pm 0.18$ & $1.33 \pm 0.12$ \\
$\mathrm{Se}$ & 1 & $1.04 \pm 0.20$ & $1.00 \pm 0.10$ \\
$\mathrm{U}$ & 1 & $1.17 \pm 0.15$ & $1.15 \pm 0.05$ \\
$\mathrm{Zn}$ & 10 & $0.98 \pm 0.09$ & $0.96 \pm 0.06$ \\
& & &
\end{tabular}

The results (in relative units) found by using standardized water samples are presented in Fig. 1. They show clearly the reproducibility and the accuracy for the different elements. Mean values and standard deviations, again given in fractions of the accurate value, are indicated in Fig. 1 and in Table 1. In the last column of this table the values calculated according to NALIMOW's method are given, for comparison.

Results obtained for different kinds of water, tap water (Darmstadt), river water (Rhein) and lake water (Lago Maggiore) have already been published. ${ }^{1}$ 

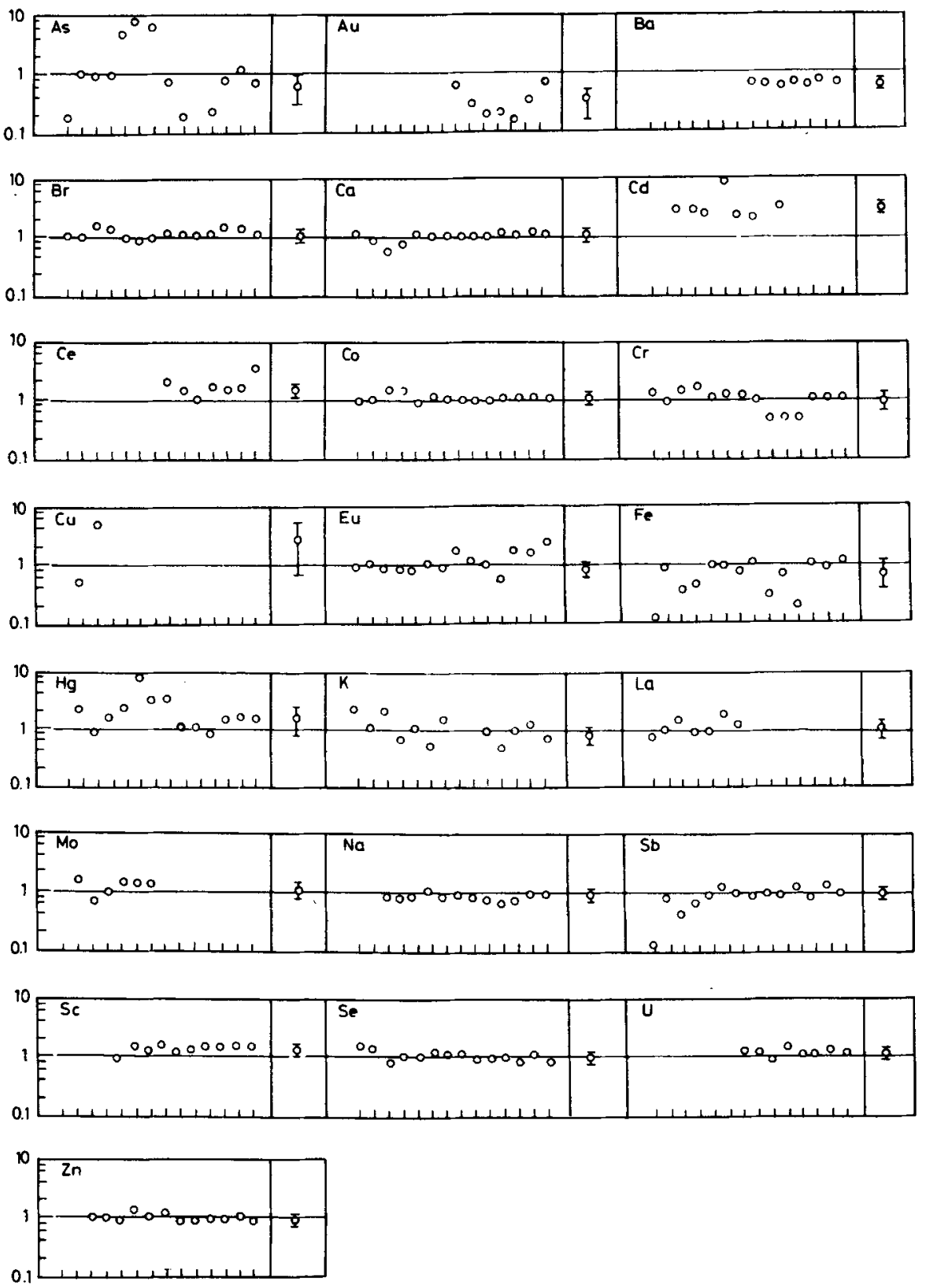

Fig. 1.Reproducibility and accuracy found by freeze-drying and application of the Fe-monostandard method for water samples of known content (standardized water samples). The real concentrations corresponding to the value 1 are listed in Table 1 


\section{K. H. LIESER et al.: NEUTRON ACTIVATION AS A ROUTINE METHOD}

Standardized water obtained by dissolution of salts in appropriate amounts and composition is used for the preparation of multielement standards by freeze-drying or adsorption for trace element determination in tap water, river water and sea water.

\section{Adsorption of trace elements on char coal}

A method of preconcentration developed in Darmstadt is shaking the water with appropriate amounts of pure activated carbon and complexing agents. This procedure leads to an adsorption of a great number of the trace elements or their complexes on the surface of the char coal whereas the alcali ions, especially sodium, remain in the solution. Char coal is an adsorbent which is not activated by thermal neutrons and can be obtained in high purity. Results of neutron activation analysis of different adsorbents, complexing agents and quartz samples are given in Table 2. They show the relatively high purity of activated char coal "Carbopuron 4n" (Degussa), which was selected for the further experiments. 1 liter standardized water with the composition of sea water was shaken with $60 \mathrm{mg}$ char coal for 15 minutes. Complexing agents were added in amounts of $1 \mathrm{mg}$, dissolved in $1 \mathrm{ml}$ acetone. The $\mathrm{pH}$ was 5.5 or it was adjusted to 8.5 by addition of $0.1 \mathrm{M}$ ammonia. The char coal was filtered off and irradiated. Results of three sets of experiments with char coal alone, char coal in presence of dithizone and char coal in presence of sodium diethyldithiocarbaminate (NaDDTC) are presented in Table 3. The following elements are adsorbed to an extent from 75 to $100 \%$ : $\mathrm{Ag}, \mathrm{Au}, \mathrm{Ce}$, $\mathrm{Cd}, \mathrm{Co}, \mathrm{Cr}, \mathrm{Eu}, \mathrm{Fe}, \mathrm{Hg}, \mathrm{La}, \mathrm{Sc}, \mathrm{U}, \mathrm{Zn}$. The amount of $\mathrm{Na}$ is reduced to about $10^{-6}, \mathrm{Br}$ to about $10^{-5}$ and $\mathrm{Ca}$ to about $10^{-2}$. The separation of the trace elements is reproducible within certain limits. On the basis of reproducibility of the separation a correction for the values found is possible.

The application of the method is most favourable for sea water. The main advantages are: High reduction of $\mathrm{NaCl}$ content, application of the method directly after collection of the samples, no storage problems, no restriction of the volume of the water samples, fast and simple separation. After filtration and drying at $80^{\circ} \mathrm{C}$ the carbon samples are filled in quartz ampoules for irradiation.

The following procedure was found to be most efficient: 1 liter of sea water is first shaken at pH 5.5 with a suspension of $30 \mathrm{mg}$ char coal and $1 \mathrm{ml}$ of an acetone solution containing $1 \mathrm{mg} \mathrm{NaDDTC}$. After filtration the solution is brought to $\mathrm{pH} 8.5$ by addition of $0.1 \mathrm{M}$ ammonia and shaken again with a suspension of $30 \mathrm{ml}$ char coal and $1 \mathrm{ml}$ of an acetone solution containing $1 \mathrm{mg}$ dithizone. Both fractions of char coal are combined, dried and filled into a quartz ampoule for irradiation. Using this procedure sea water from the north sea was analyzed. The trace 
K. H. LIESER et al.: NEUTRON ACTIVATION AS A ROUTINE METHOD

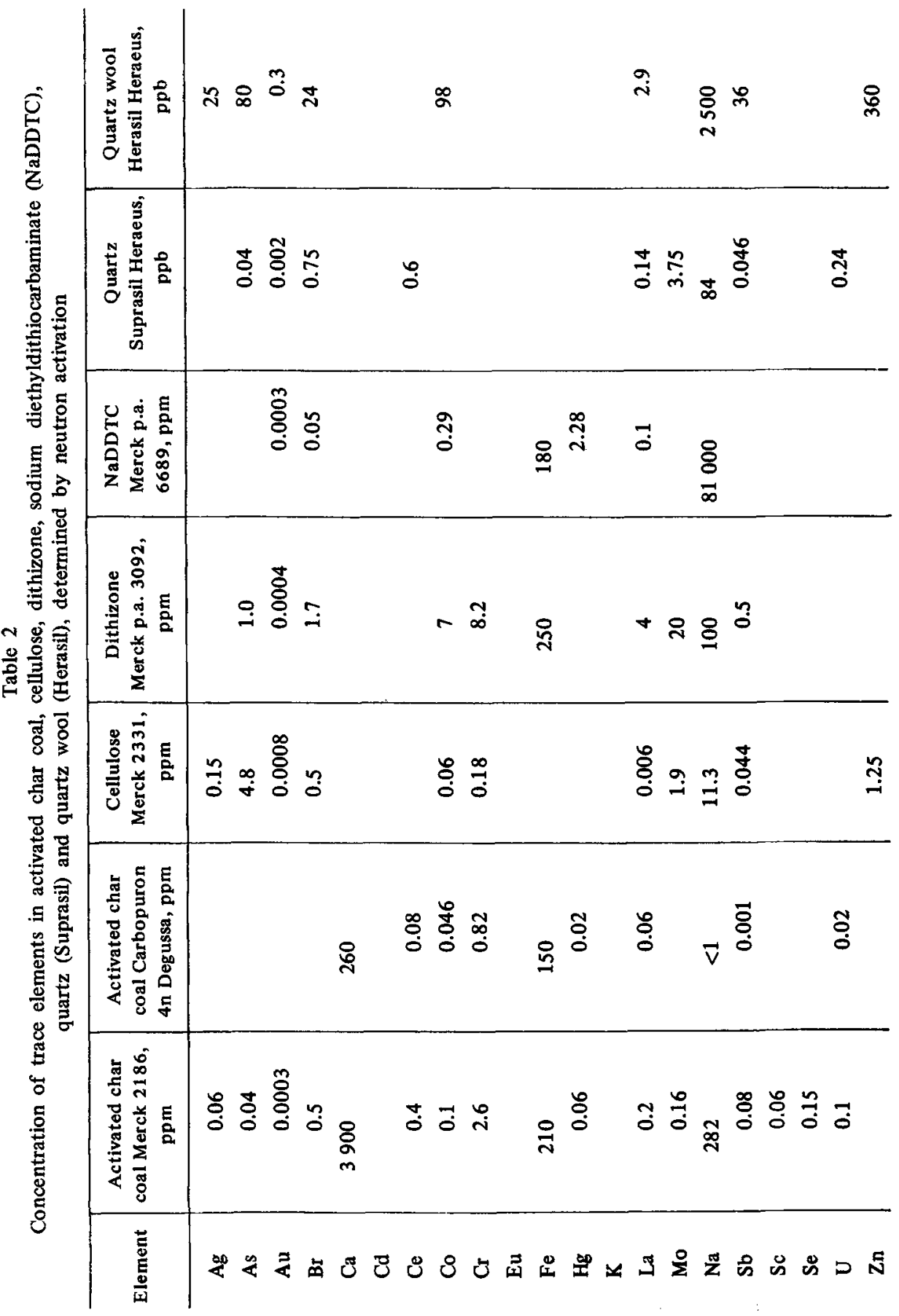


K. H. LIESER et al.: NEUTRON ACTIVATION AS A ROUTINE METHOD

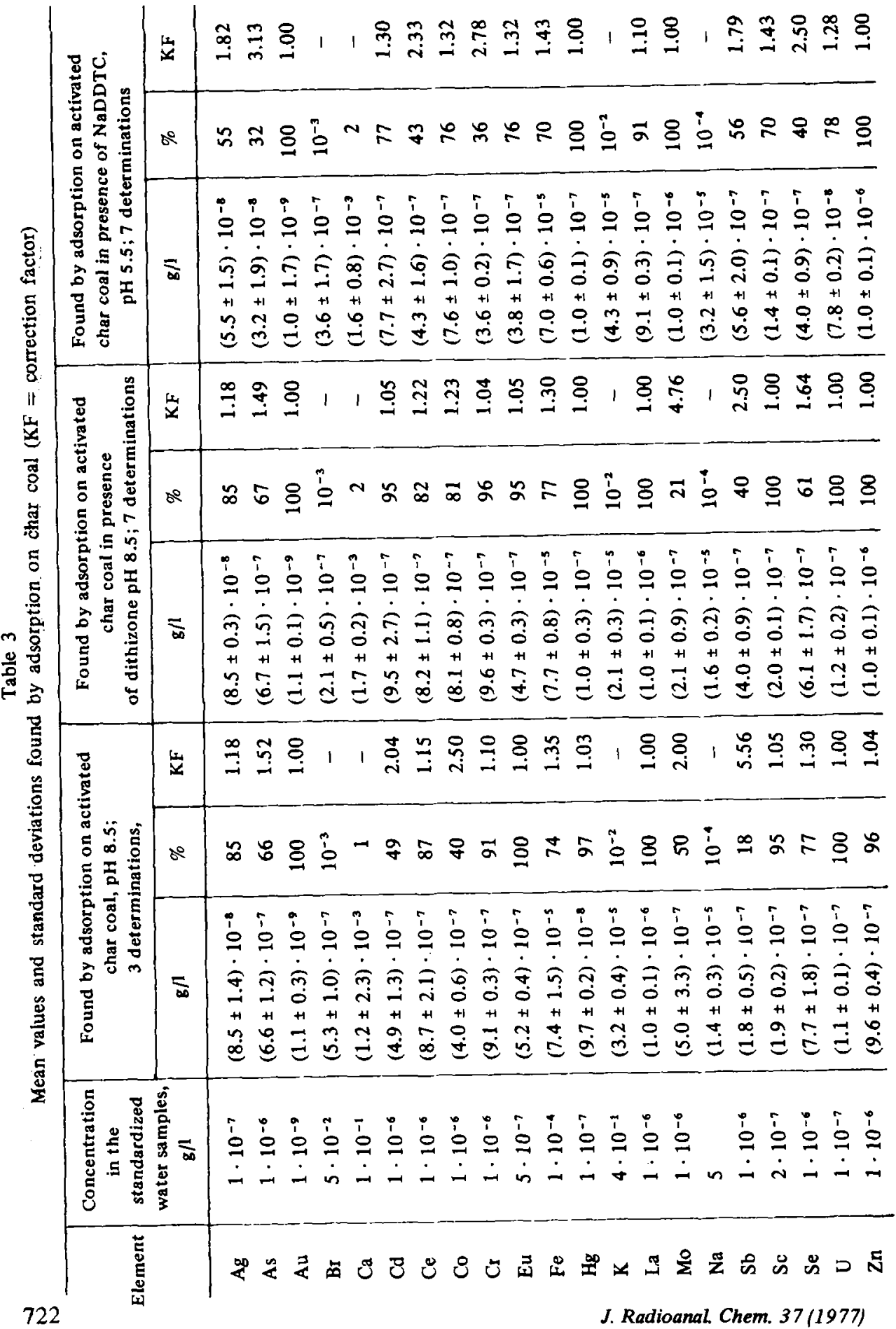




\section{K. H. LIESER et al.: NEUTRON ACTIVATION AS A ROUTINE METHOD}

Table 4

Determination of trace-elements in seawater (mean values and standard-deviations).

Samples taken at $54^{\circ} 3^{\prime}$ north. latitude, $6^{\circ} 30^{\prime}$ east. longitude, in the North Sea

\begin{tabular}{|c|c|c|c|}
\hline Element & $\begin{array}{c}\text { Water without } \\
\text { suspended material; } \\
\text { 5-determinations, } \\
\text { g/ }\end{array}$ & $\begin{array}{l}\text { Suspended material; } \\
5 \text { determinations; } \\
\text { g/1 }\end{array}$ & $\begin{array}{c}\text { Water with } \\
\text { suspended material; } \\
3 \text { determinations, } \\
\mathrm{g} / \mathbf{l}\end{array}$ \\
\hline $\mathbf{A g}$ & $(8.8 \pm 0.4) \cdot 10^{-9}$ & $(3.6 \pm 0.3) \cdot 10^{-9}$ & $(8.7 \pm 0.4) \cdot 10^{-9}$ \\
\hline As & $(3.5 \pm 0.3) \cdot 10^{-7}$ & $(3.4 \pm 1.2) \cdot 10^{-8}$ & $(4.7 \pm 0.7) \cdot 10^{-7}$ \\
\hline $\mathbf{A u}$ & $(3.5 \pm 0.3) \cdot 10^{-10}$ & $(4.5 \pm 2.0) \cdot 10^{-10}$ & $(3.9 \pm 0.2) \cdot 10^{-10}$ \\
\hline $\mathrm{Ba}$ & $(5.7 \pm 0.1) \cdot 10^{-7}$ & $(4.1 \pm 0.6) \cdot 10^{-7}$ & $(1.3 \pm 0.5) \cdot 10^{-6}$ \\
\hline $\mathrm{Br}$ & $(5.5 \pm 0.1) \cdot 10^{-7}$ & $(4.0 \pm 3.8) \cdot 10^{-6}$ & $(3.7 \pm 0.2) \cdot 10^{-6}$ \\
\hline $\mathrm{Ca}$ & $(3.6 \pm 0.2) \cdot 10^{-5}$ & $(1.5 \pm 0.3) \cdot 10^{-4}$ & $(2.0 \pm 0.5) \cdot 10^{-4}$ \\
\hline Cd & $<10^{-8}$ & $<10^{-8}$ & $<10^{-8}$ \\
\hline $\mathrm{Ce}$ & $(3.4 \pm 0.3) \cdot 10^{-8}$ & $(2.4 \pm 1.5) \cdot 10^{-8}$ & $(1.0 \pm 0.2) \cdot 10^{-8}$ \\
\hline Co & $(4.5 \pm 0.3) \cdot 10^{-8}$ & $(2.3 \pm 0.8) \cdot 10^{-8}$ & $(6.7 \pm 0.2) \cdot 10^{-8}$ \\
\hline $\mathrm{Cr}$ & $(1.4 \pm 0.1) \cdot 10^{-2}$ & $(1.3 \pm 0.3) \cdot 10^{-7}$ & $(2.9 \pm 0.2) \cdot 10^{-7}$ \\
\hline Eu & $(8.2 \pm 1.4) \cdot 10^{-10}$ & $(4.4 \pm 1.9) \cdot 10^{-9}$ & $(5.6 \pm 1.7) \cdot 10^{-9}$ \\
\hline $\mathrm{Fe}$ & $(1.5 \pm 0.2) \cdot 10^{-5}$ & $(3.5 \pm 1.2) \cdot 10^{-5}$ & $(6.8 \pm 1.5) \cdot 10^{-5}$ \\
\hline Hg & $(2.2 \pm 0.2) \cdot 10^{-8}$ & $<5 \cdot 10^{-9}$ & $<5 \cdot 10^{-9}$ \\
\hline $\mathbf{K}$ & $(3.6 \pm 1.9) \cdot 10^{-5}$ & $(2.9 \pm 0.7) \cdot 10^{-5}$ & $(4.7 \pm 1.4) \cdot 10^{-5}$ \\
\hline $\mathbf{L a}$ & $(3.2 \pm 0.1) \cdot 10^{-8}$ & $(2.8 \pm 2.1) \cdot 10^{-8}$ & $(7.4 \pm 1.4) \cdot 10^{-8}$ \\
\hline Mo & $(4.4 \pm 1.4) \cdot 10^{-8}$ & $(2.1 \pm 0.1) \cdot 10^{-8}$ & $(6.1 \pm 0.5) \cdot 10^{-\mathrm{s}}$ \\
\hline $\mathrm{Na}$ & $(3.6 \pm 0.3) \cdot 10^{-4}$ & $(4.7 \pm 6.9) \cdot 10^{-4}$ & $(1.7 \pm 0.7) \cdot 10^{-4}$ \\
\hline $\mathrm{Sb}$ & $(5.7 \pm 0.4) \cdot 10^{-9}$ & $(2.3 \pm 0.8) \cdot 10^{-9}$ & $(1.3 \pm 0.2) \cdot 10^{-8}$ \\
\hline Sc & $(4.5 \pm 0.3) \cdot 10^{-8}$ & $(1.9 \pm 2.0) \cdot 10^{-8}$ & $(2.3 \pm 0.4) \cdot 10^{-8}$ \\
\hline $\mathrm{Se}$ & $(4.5 \pm 0.3) \cdot 10^{-8}$ & $(3.5 \pm 0.9) \cdot 10^{-8}$ & $(6.3 \pm 0.7) \cdot 10^{-8}$ \\
\hline $\mathrm{U}$ & $(3.3 \pm 1.0) \cdot 10^{-8}$ & $(1.5 \pm 0.8) \cdot 10^{-8}$ & $(5.6 \pm 0.9) \cdot 10^{-8}$ \\
\hline $\mathbf{Z n}$ & $(2.3 \pm 0.1) \cdot 10^{-6}$ & $(3.3 \pm 1.5) \cdot 10^{-7}$ & $(3.9 \pm 0.2) \cdot 10^{-6}$ \\
\hline
\end{tabular}

elements were determined in the water together with the suspended material, in the suspended material alone and in filtered water. The results are presented in Table 4. They have been confirmed by independent determination for the elements $\mathrm{Co}, \mathrm{Fe}, \mathrm{Hg}, \mathrm{Sb}, \mathrm{Sc}, \mathrm{U}, \mathrm{Zn}$.

\section{Suspended material}

A number of water samples from rivers were filtered using membrane filters and the trace elements in the suspended material as well as in the solution were determined separately. Results for the Main river at different sites and times are given 
Table 5

Distribution of elements between solution and suspended matter in the Main river.

Sample I from Main river (11.3.75, Frankfurt, middle of the river); sample II from Main river (24.3.76, Frankfurt, near the left bank of the river)

\begin{tabular}{|c|c|c|c|c|}
\hline \multirow{2}{*}{ Element } & \multicolumn{2}{|c|}{ Sample I } & \multicolumn{2}{|c|}{ Sample II } \\
\hline & $\begin{array}{c}\text { Solution, } \\
\%\end{array}$ & $\begin{array}{c}\text { Suspended } \\
\text { matter, } \%\end{array}$ & $\begin{array}{c}\text { Solution, } \\
\%\end{array}$ & $\begin{array}{l}\text { Suspended } \\
\text { matter, } \%\end{array}$ \\
\hline Ag & - & - & 11.1 & 88.9 \\
\hline As & 91.5 & 8.5 & 70.7 & 29.3 \\
\hline Au & 66.6 & 33.4 & 44.7 & 55.3 \\
\hline $\mathbf{B a}$ & 84.0 & 16.0 & 85.7 & 14.3 \\
\hline $\mathrm{Br}$ & 99.0 & 1.0 & 99.0 & 1.0 \\
\hline $\mathrm{Ca}$ & - & - & 99.5 & 0.5 \\
\hline $\mathrm{Ce}$ & 20.4 & 79.6 & 47.5 & 52.5 \\
\hline Co & 66.6 & 33.4 & 57.8 & 42.2 \\
\hline $\mathrm{Cr}$ & 25.0 & 75.0 & 25.0 & 75.0 \\
\hline Cs & 38.0 & 62.0 & 12.5 & 87.5 \\
\hline $\mathrm{Eu}$ & 23.1 & 76.9 & - & - \\
\hline $\mathrm{Fe}$ & 9.3 & 90.7 & 21.0 & 79.0 \\
\hline Hf & 9.1 & 90.9 & - & - \\
\hline $\mathbf{K}$ & 93.0 & 7.0 & 96.0 & 4.0 \\
\hline La & 30.0 & 70.0 & 54.7 & 45.3 \\
\hline Mo & - & - & 97.7 & 2.3 \\
\hline $\mathrm{Na}$ & 99.8 & 0.2 & 99.9 & 0.1 \\
\hline $\mathbf{R b}$ & 58.0 & 42.0 & - & $\rightarrow$ \\
\hline $\mathrm{Sb}$ & 64.0 & 36.0 & 54.4 & 45.6 \\
\hline Sc & 3.5 & 96.5 & 2.4 & 97.6 \\
\hline $\mathrm{Se}$ & 76.0 & 24.0 & 82.6 & 17.4 \\
\hline $\mathrm{Sm}$ & 65.0 & 35.0 & - & - \\
\hline $\mathrm{U}$ & 90.9 & 9.1 & 94.0 & 6.0 \\
\hline$Z_{n}$ & 64.0 & 36.0 & 66.4 & 33.6 \\
\hline
\end{tabular}

in Table 5. The variations of the elements with place and time are in most cases not significant. The following elements are enriched in the suspended material: $\mathrm{Ag}$, $\mathrm{Ce}, \mathrm{Cr}, \mathrm{Cs}, \mathrm{Eu}, \mathrm{Fe}, \mathrm{Hf}, \mathrm{La}, \mathrm{Sc}$. The percentage found in the suspended material is $\langle 10 \%$ for $\mathrm{Br}, \mathrm{Ca}, \mathrm{K}, \mathrm{Mo}, \mathrm{Na}$ and $\mathrm{U}$. The alcali elements exhibit increasing adsorption with atomic number, ranging from $0.1 \%$ for $\mathrm{Na}$ to $62 \%$ for $\mathrm{Cs}$. It may be assumed that $\mathrm{Cs}$ is bound in the clay particles by ion exchange. 


\section{K. H. LIESER et al.: NEUTRON ACTIVATION AS A ROUTINE METHOD}

Table 6

Preliminary values for the mobility of the elements in the suspended material, as calculated from the fraction taking part in the exchange between suspended material and solution

\begin{tabular}{c|c|c|c}
\hline Element & $\begin{array}{c}\text { Fraction of } \\
\text { exchange calculated } \\
\text { for 100\% mobility }\end{array}$ & $\begin{array}{c}\text { Fraction of } \\
\text { exchange found }\end{array}$ & $\begin{array}{c}\text { Mobility, } \\
\%\end{array}$ \\
\hline $\mathrm{Ag}$ & 0.05 & $0.09 \pm 0.02$ & 100 \\
$\mathrm{Au}$ & 0.25 & $0.25 \pm 0.14$ & 100 \\
$\mathrm{Ba}$ & 0.71 & $0.11 \pm 0.03$ & 16 \\
$\mathrm{Ce}$ & 0.27 & $0.19 \pm 0.01$ & 70 \\
$\mathrm{Co}$ & 0.37 & $0.36 \pm 0.01$ & 100 \\
$\mathrm{Cr}$ & 0.12 & $0.16 \pm 0.01$ & 100 \\
$\mathrm{Fe}$ & 0.10 & $0.18 \pm 0.01$ & 100 \\
$\mathrm{Sb}$ & 0.33 & $0.15 \pm 0.01$ & 46 \\
$\mathrm{Zn}$ & 0.45 & $0.27 \pm 0.05$ & 60
\end{tabular}

In order to obtain an indication of the mobility of the elements in the suspended matter which is given by the fraction exchanged between suspended matter and solution the following experiments were made: Suspended matter and solution were separated in a centrifuge. The suspended matter was dried at $80^{\circ} \mathrm{C}$, irradiated and mixed with the original solution. Alternatively the filtered solution was freezedried, irradiated, dissolved and mixed with the suspended matter. After shaking for about 1 day solution and suspended matter were separated again. Some preliminary values which have been obtained up to now are given in Table 6 . Furthermore some experiments have been performed in which the suspended matter was treated either with water or with acetone or with diluted $\mathrm{HCl}$ in order to obtain values for the solubility of the trace elements in these solvents and hence an indication of the chemical form and the physical state of the elements. By treatment with water some elements are dissolved partially: $\mathrm{Ba}, \mathrm{Ca}, \mathrm{Na}$. The treatment with acetone is not very effective, whereas the treatment with dilute $\mathrm{HCl}$ dissolves appreciable amounts of $\mathrm{Ba}, \mathrm{Ca}, \mathrm{Co}, \mathrm{Cr}, \mathrm{Na}$ and $\mathrm{Zn}$. The results may be compared with former investigations. ${ }^{2,3}$

\section{Conclusions}

Freeze-drying as routine method gives reliable results for a great number of elements. Adsorption of trace elements on char coal in presence of complexing agents, especially at two different $\mathrm{pH}$ values and using two different complexing agents 
represents a new very simple method for the determination of trace elements in sea water. The investigation of exchange equilibria by different methods gives information on the mobility of the trace elements in the suspended material.

\section{References}

1. K. H. LIESER, V. NEITZERT, J. Radioanal. Chem., 31 (1976) 397.

2. U. FORSTNER, S. R. PATCHINEELAM, Chemikerzeitung, 100 (1976) 49.

3. P. BENES, E. STEINESS, Water Research, 8 (1974) 947; 9 (1975) 741. 